\title{
Assessment of beyond-the-field nutrient management practices for agricultural crop systems with subsurface drainage
}

\author{
M. Kalcic, W. Crumpton, X. Liu, J. D’Ambrosio, A. Ward, and J. Witter
}

\begin{abstract}
This paper reviews the characteristics, benefits, and drawbacks of agricultural ditches and wetlands, as well as strategies for applying agricultural best management practices (BMPs) at the watershed scale for improving water quality. This synthesis focuses on the Great Lakes Region and the Mississippi River Basin in the United States, and specifically crop production systems in watersheds with subsurface drainage. The USDA Natural Resources Conservation Service (NRCS) has developed conservation practice standards for open channels and wetlands, which mitigate nutrient and sediment loading to surface water bodies from agricultural lands. Practices that use agricultural ditches to improve water quality, such as the two-stage ditch, have emerged in the last two decades and are starting to see a greater application in the region. Using wetlands as water treatment systems has a long history in a range of settings and over the past several decades is seeing more widespread application in agriculture. Water quality and watershed models are increasingly used to develop watershed strategies for reducing nutrient exports with agricultural BMPs. Models are also helpful in evaluating combinations of practices from the farm scale to the watershed scale. Application and limitations of several models commonly used in these regions of the United States are discussed. Finally, successful conservation strategies at the watershed scale must consider the human dimensions of watershed management, and we summarize the literature in this region on farmer perceptions and adoption of practices.
\end{abstract}

Key words: agricultural nutrients—best management practices (BMPs) — nutrient management - two-stage ditches — watershed models—wetlands

Throughout the world, human development drives eutrophication-or nutrient enrichment-in marine and freshwater systems, with particularly concerning impacts of harmful algal blooms (HABs) and hypoxia (NRC 2008; Diaz and Rosenburg 2008; Rabalais et al. 2010). HABs have increased in frequency and extent globally (Carmichael 2008), and blooms of harmful species, Microcystis spp., have been observed in every continent, including Antarctica (Jungblut et al. 2006). Similarly, hypoxic zones have increased exponentially in the past 50 years (Diaz and Rosenburg 2008), and agriculture is considered a primary contributor to the formation of hypoxic zones in many areas of the world.

Agricultural impacts on water quality are a particular concern in the Mississippi River and Great Lakes basins, which con- tribute some of the highest nitrogen $(\mathrm{N})$ and phosphorus $(\mathrm{P})$ loads and in-stream concentrations in the United States (figure 1). These excessive nutrient loads are likely drivers of HABs observed in waterbodies throughout the Mississippi River Basin and Great Lakes region, including the recurrence of HABs in Lake Erie, which are primarily attributed to increases in nonpoint source $\mathrm{P}$ loading (Michalak et al. 2013; Stow et al. 2015; Ward et al. 2015; Maccoux et al. 2016; Scavia et al. 2016; Watson et al. 2016). Agricultural nutrient loads are also a primary driver of hypoxia in the Gulf of Mexico (Dale et al. 2010; Goolsby et al. 2001).

These water quality impacts are attributed to the extent and intensity of agricultural production in the region, including subsurface drainage (figure 1). These subsurface drainage networks have long been recog- nized as a primary pathway for nitrate $\left(\mathrm{NO}_{3}\right)$ transport to surface waters and more recently as a pathway for P as well (Strock et al. 2007; King et al. 2015). Worldwide, more than 150 million ha (370 million ac) of agricultural land have some form of drainage, and it is estimated that an additional 300 million ha (741 million ac) would benefit from drainage improvements (Ritzema et al. 2006; Birendra et al. 2011). In the United States and Canada, drainage is required to maintain crop yields on approximately a quarter of all cropland (Pavelis 1987; Shady 1989). Drainage may be needed to remove excess water from a field, lower water tables to promote aeration in the root-zone, improve trafficability during wet periods, prevent water logging in poorly drained soils, or manage soil salinity in irrigated arid and semiarid croplands (Skaggs et al. 2012a). Often more than one of these problems will occur in a crop production system. Types of agricultural drainage systems include grassed waterways, in-field open-ditches, subsurface drainage systems, edge-of-field ditches, and constructed or modified channels that serve as drainage collection and discharge systems for multiple fields. Usually, these systems will then discharge to rivers, wetlands, reservoirs, and lakes, before sometimes reaching the ocean.

Agricultural nutrient loading can be mitigated using best management practices (BMPs). BMPs can trap nutrients and sediments near their source-in farm fields and at the edge of fields — or further downstream. It is generally accepted that conservation actions should first be targeted to the source using, for instance, the $4 \mathrm{R}$ nutrient

Margaret Kalcic is an assistant professor in the Department of Food, Agricultural, and Biological Engineering at The Ohio State University in Columbus, Ohio. William Crumpton is a professor in the Department of Ecology, Evolution, and Organismal Biology at lowa State University in Ames, lowa. Xiaoqiang Liu is a post-doctoral scholar in the Department of Food, Agricultural, and Biological Engineering at Ohio State University in Columbus, Ohio. Jessica D'Ambrosio is project director for Western Lake Erie Basin Agriculture with The Nature Conservancy in Defiance, Ohio. Andrew Ward is a professor in the Department of Food, Agricultural, and Biological Engineering at The Ohio State University in Columbus, Ohio. Jonathan Witter is an assistant professor in the Agricultural Technical Institute at Ohio State University in Wooster, Ohio. 
management principles (Vollmer-Sanders et al. 2016), but these source-specific practices may not be sufficient to reach nutrient goals (Scavia et al. 2017), and a systems approach to conservation often includes off-site practices. In landscapes with hydrology dominated by subsurface drainage, in-stream and in-ditch practices may be critical to intercepting nutrients that are difficult to capture through in-field and edge-of-field practices (King et al. 2015). This paper summarizes water quality BMPs in landscapes with subsurface drainage, focusing primarily on treatment of sediments, $\mathrm{N}$, and $\mathrm{P}$ in drainage ditches and constructed wetlands, as well as considering challenges to implementing conservation practices at the watershed scale, including use of models and barriers to adoption of BMPs.

\section{Open Channels (USDA Natural Resources Conservation Service Conservation Practice Standard Code 582)}

Hydrology and Sediment Transport in Streams, Ditches, and Channels. It has been estimated that in parts of the Midwest at least $80 \%$ of the stream network has been channelized and modified to a trapezoidal geometry for agricultural purposes (Blann et al. 2009). Trapezoidal-shaped channels drain the soil profile and efficiently convey water downstream, yet they are often hydrologically disconnected from floodplains and sized to be wider and deeper ( 2 to $5 \mathrm{~m}$ [6.56 to $16.4 \mathrm{ft}]$ ) than streams formed by natural fluvial processes. If left unmaintained, disturbed headwater systems tend to develop stable geomorphic features, similar to natural streams, such as an inset channel, bars, and vegetated benches (figure 2) (Kuhnle et al. 1999; Rhoads et al. 1999; Frothingham et al. 2002; Landwehr and Rhoads 2003; Jayakaran et al. 2005; Jayakaran and Ward 2007). If a ditch is too wide, the bottom of the ditch adjusts to a narrower width to form an inset channel by building benches (Landwehr and Rhoads 2003; Jayakaran and Ward 2007).

Progression to more stable geomorphology can compromise the original purpose of drainage ditches - draining the soil profile to maintain crop yields - through burying subsurface drain outlets and increasing hydraulic residence times (Blann et al. 2009). They are, therefore, maintained every few years to remove vegetation and sediment deposits and restore the trapezoidal shape that sustains drainage capacity. In many cases

\section{Figure 1}

Spatial distribution of (a) land cover from Landsat data, (b) estimated extent of subsurface drainage, and (c) nitrate-nitrogen ( $\mathrm{NO}_{3}-\mathrm{N}$ ) concentrations estimated from STORET for the Upper Mississippi River and Ohio River basins (adapted from Crumpton et al. 2006).

(a)

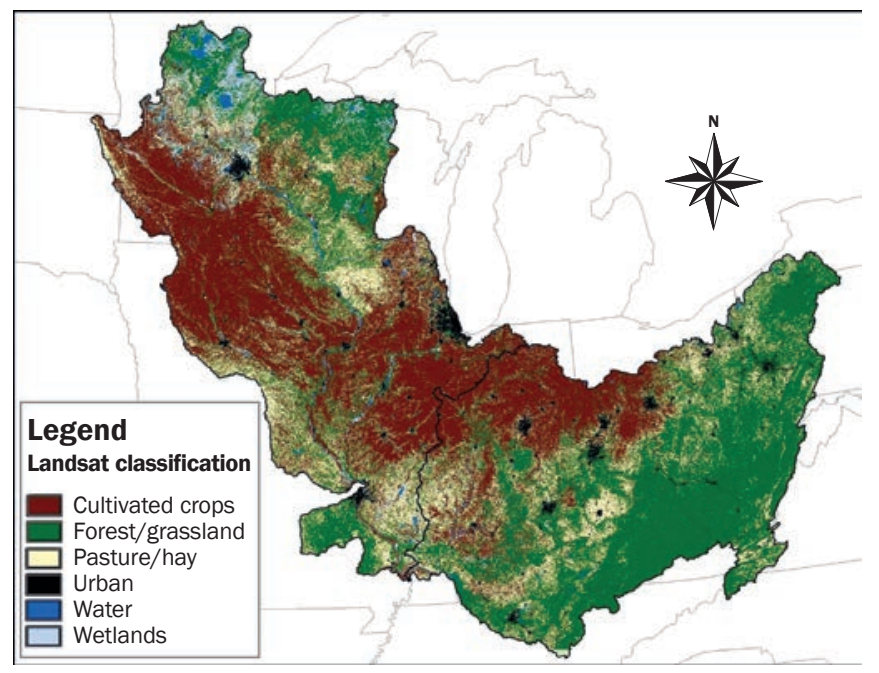

(b)

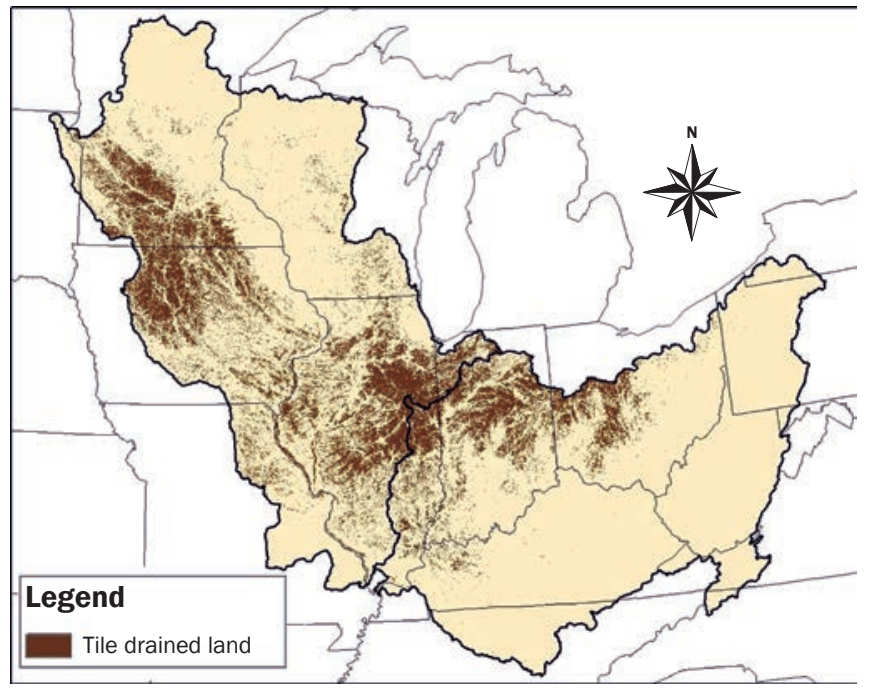

(c)

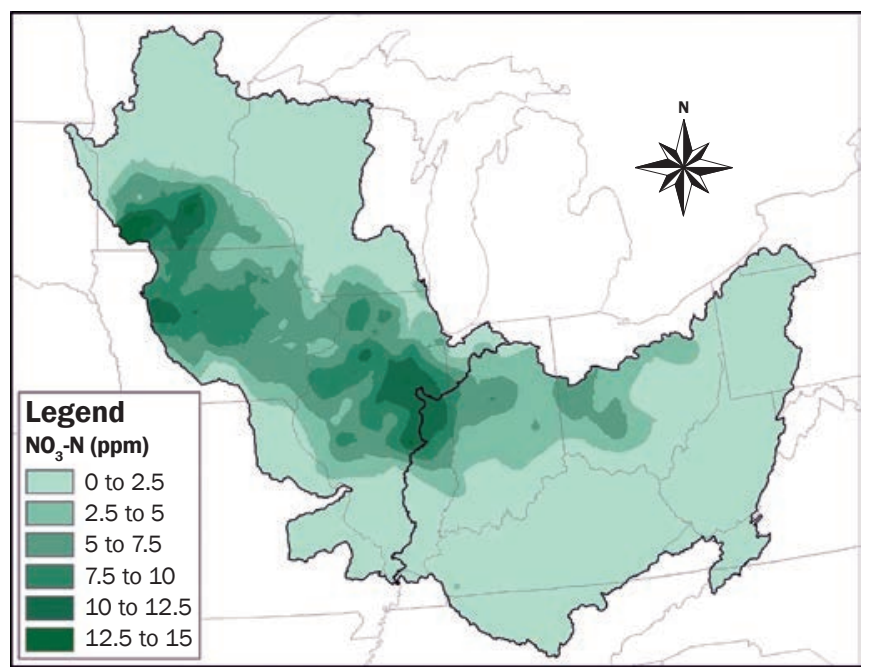




\section{Figure 2}

An agricultural drainage ditch in Ohio with naturally formed vegetated benches and a meandering inset channel.

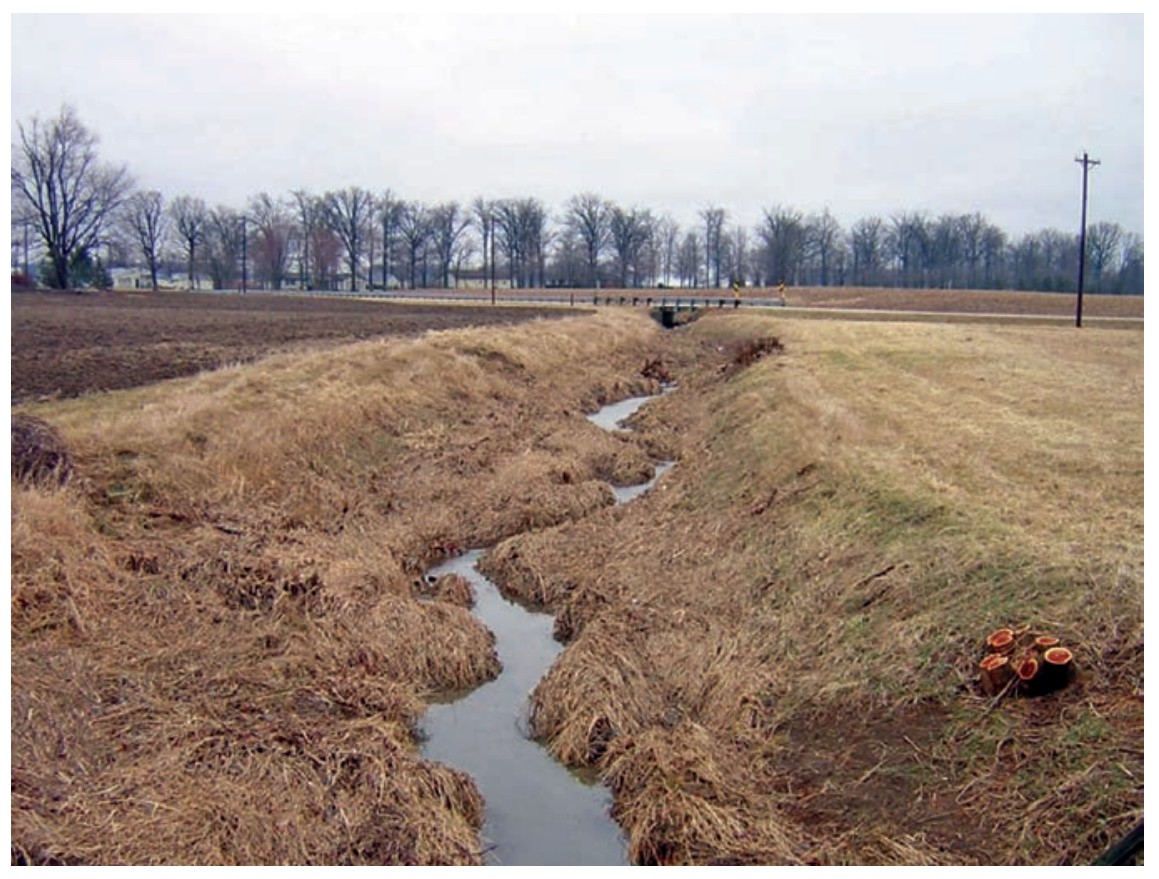

maintenance activities lead to higher flow velocities, which destabilize channel beds and steepen unvegetated banks, resulting in further deepening and widening of channels (Daniels 1960; Emerson 1971; Nunnally 1978; Ritter 1979; Simon and Rinaldi 2006). The newly formed and still oversized channel fails to transport sediment, and as aggradation flattens the channel's slope, the hydraulic residence time is again increased, perpetuating the fluvial cycle of imbalance.

Nutrient Reduction in Open Ditches. Considerable research establishes the disruptive role that channelization and channel maintenance plays in the natural buffering of nonpoint source pollutants (Kleinman et al. 2007; Smith and Pappas 2007; Pappas and Smith 2007), and the simple act of vegetating open ditches can be a BMP for agricultural contaminants (Jayakaran et al. 2010; Strock et al. 2010). In contrast, Smith and Huang (2010) in a study of two ditches in Indiana, found that dredging improved nutrient reduction. Skaggs et al. (1994) reviewed the impact of drainage on water quality and found that land clearing, channelization of streams, and subsurface drainage affect peak flows, runoff, sedimentation, and $\mathrm{N}$ and $\mathrm{P}$ levels in stream systems. Agricultural streams may be capable of removing as much as $10 \%$ to $70 \%$ of $\mathrm{NO}_{3}$ loading in a watershed (Birgand et al. 2007), yet they transport most $\mathrm{NO}_{3}$ during high flow events when removal capacity is low (Royer et al. 2006). Retaining vegetated benches increases the surface area of ditches and retention time during high flows. In Ohio and Indiana, denitrification rates have been found to be greater in sediments on naturally formed ditch benches than in sediments from side slopes of maintained trapezoidal ditches (Powell and Bouchard 2010), and having benches may influence in-stream denitrification rates (Roley et al. 2012a, 2012b). Managing flow regimes in ditches can reduce $\mathrm{N}$ and moderate downstream $\mathrm{P}$ losses through greater capacity for sorption (Needelman et al. 2007; Strock et al. 2007, 2010; Smith 2009). Managing floodplains of ditch systems, either in the channel (Powell et al. 2007a, 2007b) or adjacent to it (Evans et al. 2007; King et al. 2015), can be effective in reducing sediment and nutrient losses from agricultural watersheds.

\section{Two-Stage Ditches}

Hydrology and Sediment Transport in TwoStage Ditches. The two-stage ditch is a floodplain establishment design that is based on principles of fluvial geomorphology to be self-sustaining and reduce or eliminate the need for clean-out activities in trapezoi- dal ditches (Jayakaran et al. 2005; Jayakaran and Ward 2007; Powell et al. 2007a, 2007b; Rhoads and Massey 2012; Magner et al. 2012). They are particularly suitable for landscapes having subsurface drainage, which alters channel hydrology, forming inset channels in receiving ditch systems by discharges associated with high subsurface drainage flows. Jayakaran et al. (2005), using a logistic regression model, found that stable bench formation could be predicted by the width of the ditch and drainage area in northwest Ohio ditches, and that stable ditches can be sized to accommodate extreme events. Designing two-stage ditches requires sizing an inset-or main-channel to convey bankfull discharge, as well as floodplain benches with the capacity to convey high flows without flooding surrounding cropland (figure 3) (Powell et al. 2007a, 2007b). The stage and width of the constructed floodplain benches are determined from regional curves that relate the expected bankfull geometry of the main channel to drainage area (figure 4). Figure 4 shows an example of regional curves that were developed based on surveys of ditches and modified headwater streams that exhibited bench features. In theory, a two-stage geometry results in a channel sized by channel-forming processes that are in a stable, quasi-equilibrium state (Schumm 1981; Simon and Hupp 1986; Nanson and Croke 1992). Recurrence intervals of channel-forming discharges in modified low gradient watersheds dominated by subsurface drainage are often less than the frequently reported 1.3-year to 2 -year recurrence interval, which are the published values commonly used for engineering design (Jayakaran 2005; Powell et al. 2006; Simon et al. 2004).

The first two-stage ditch designed using engineering principles and channel-forming concepts was constructed in Wood County, Ohio, in 2002 (Powell 2006; Powell et al. 2007a, 2007b). The primary goal of the project was to increase the capacity of the undersized ditch and thereby reduce flooding of adjacent fields after rain events. The project was considered a prototype for future two-stage channels, and it led to the development of a nine-step procedure outlining the design of two-stage ditches (Powell et al. 2007a). Powell et al. (2007b) provide a case study review of the first eight twostage ditch projects in Ohio, Indiana, and Michigan, designed or constructed using this 
Figure 3

Schematic comparing (a) conventional trapezoidal ditch design and (b) two-stage ditch design (D'Ambrosio et al. 2015).

(a)

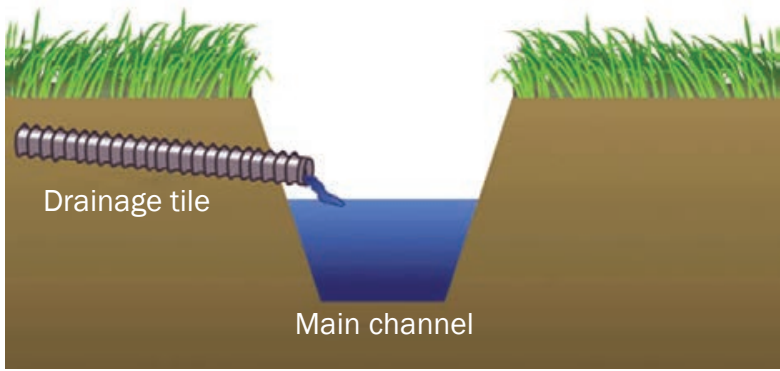

(b)

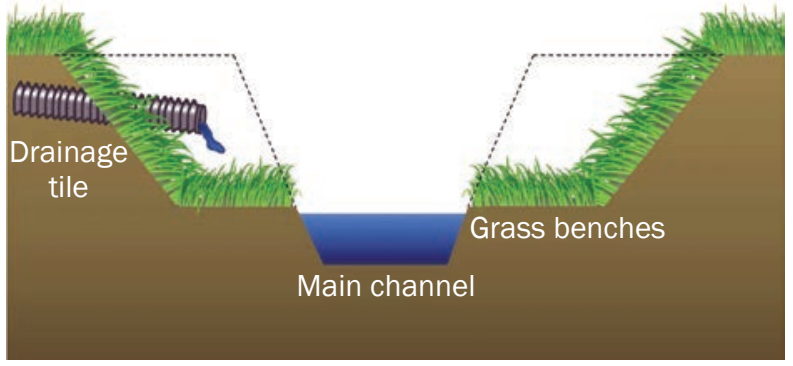

procedure. Ward et al. (2008) investigated floodplain ratios in constructed two-stage channels that would maximize bench stability, provide floodplain benefits, and minimize lateral migration of the inset channel within the ditch, and concluded that benches should be constructed at a width of three to five times the expected bankfull width of the inset channel. At the time of publication only Indiana and Ohio have included twostage ditches in their open channel USDA Natural Resources Conservation Service (NRCS) Conservation Practice Standard Code 582, but several documents provide guidance on the design of two-stage ditches (USDA NRCS 2007; USDA NRCS 2014; Witter 2013).

D'Ambrosio et al. (2015) evaluated the evolution of two-stage channels in Ohio, Indiana, and Michigan that were designed and constructed using the nine-step procedure outlined in Powell et al. (2007a). They assessed where geomorphic changes were occurring over time (i.e., scour on ditch side slopes, scour or deposition on constructed benches, and aggradation or degradation of the inset channel), if ditches were maintaining drainage capacity, and what maintenance had been needed since construction. Three to eleven years after construction, D'Ambrosio et al. (2015) found little change in the dimensions of these ditches, as ditches had remained stable, required no traditional clean-out since construction, and sustained both their overall ditch capacity and an inset channel (figure 5). Therefore, two-stage ditch modification, with a goal to improve bank stability and/ or reduce flooding into adjacent fields, had successfully achieved these goals.

A number of others have studied the hydrology and sediment transport in agricultural two-stage ditches. Kallio (2009) found

\section{Figure 4}

Regional curves developed for agricultural drainage ditches in Indiana, Michigan, and Ohio used to size the main or inset channel of a two-stage ditch. Measured bankfull inset channel dimensions $(\mathrm{D}=$ depth, $\mathrm{W}=$ width, and $\mathrm{A}=$ cross-sectional area) are a function of drainage area.

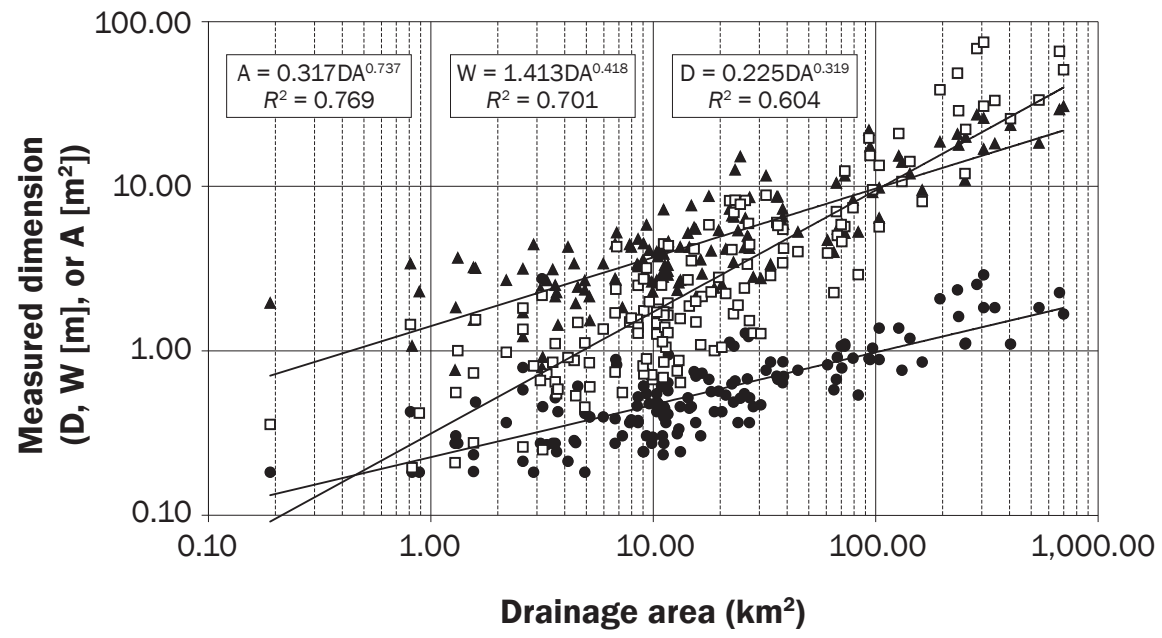

\section{Legend}

- Depth tri-state

Width tri-state

$\square$ Area tri-state

that low benches were flooded for 10 to 60 days a year, and flooding tended to occur when streamflow exceeded $30 \%$ of the twoyear discharge. Fry et al. (2012) found that overbank flow was $1 \%$ to $4 \%$ of the total volume of flow in a small agricultural watershed with attached floodplains. Rhoads and Massey (2012) found that lateral migration of a naturally formed inset channel that had well-vegetated benches was small.

The two-stage ditch design has also been implemented and monitored in Europe. Västilä and Järvelä (2011) and Västilä et al. (2016), in a study of a two-stage ditch in Finland, concluded that appropriate vegetation maintenance in these ditches provides the potential to control sediment processes. In 2010, $850 \mathrm{~m}(2,789 \mathrm{ft})$ of the Ritobäcken Brook in Sipoo, Southern Finland, was modified to a two-stage ditch to convey high flows, and they found spatially averaged deposition on the floodplain of $3.4 \%$ to $5.5 \%$ the total suspended sediment load, similar to agricultural floodplains in Denmark (Kronvang et al. 2009) and the United Kingdom (Walling and Amos 1999). This rate of floodplain deposition suggests stability, although seasonal erosion on the 
floodplain is possible, similar to channel bed erosion from the growth and die-back of aquatic vegetation (Cotton et al. 2006; Heppell et al. 2009).

Nutrient Reduction Benefits of Two-Stage Ditches. Nutrient removal benefits of twostage ditches depend on the frequency the benches are saturated and the ability of the benches to serve as biological treatment systems. A simulation study found that if $1 \%$ of a watershed was converted to benches within ditches, the increased storage could remove up to $20 \%$ of $\mathrm{NO}_{3}-\mathrm{N}$ loading in the system (Kallio 2010). There is extensive research on quantifying $\mathrm{N}$ removal rates and sediment dynamics in several ditches in Indiana, Michigan, and Ohio (Roley et al. 2012a, 2012b; Roley et al. 2014; Davis et al. 2015). At a constructed two-stage ditch in the Tippecanoe River watershed in Indiana, monitoring began one year prior to two-stage construction in both an upstream control and a downstream treatment reach and has continued for several years postconstruction. The two-stage ditch conversion improved reach-scale $\mathrm{N}$ removal by increasing bioreactive surface area through the construction of the floodplain benches. In comparing the two-stage treatment reach to the upstream control reach, there was a $43 \%$ decrease in mean daily turbidity in the two-stage reach in the two-year period postconstruction. They report that the reduction in turbidity is likely a combination of reduced stream erosion and increased particle deposition on floodplain benches. The results suggest that two-stage ditches can improve water quality through $\mathrm{NO}_{3}$ removal, due to greater surface area from benches, and reduce turbidity, which may correspond to a reduction in $\mathrm{P}$ export from these systems.

Roley et al. (2012a) reported that the main factors that influenced $\mathrm{NO}_{3}$ removal efficiency were the organic matter content of the constructed floodplain (benches), the concentration of $\mathrm{NO}_{3}$, the length of time benches were flooded, and the size of the floodplain relative to the watershed (catchment) area. For example, in 2008 floodplain inundation was 29 days and contributed to $12 \%$ of the $\mathrm{N}$ removal as compared to 2009 , in which floodplains were inundated for 132 days and contributed to $47 \%$ of the $\mathrm{N}$ removal. The two-stage ditch system comprised only $7 \%$ of the total ditch length and occupied less than $0.04 \%$ of the watershed area. Maximum $\mathrm{NO}_{3}$ removal of $28 \%$ occurred during base

\section{Figure 5}

A constructed two-stage ditch in Hillsdale County, Michigan, requiring no clean-out of the main channel six years after construction.

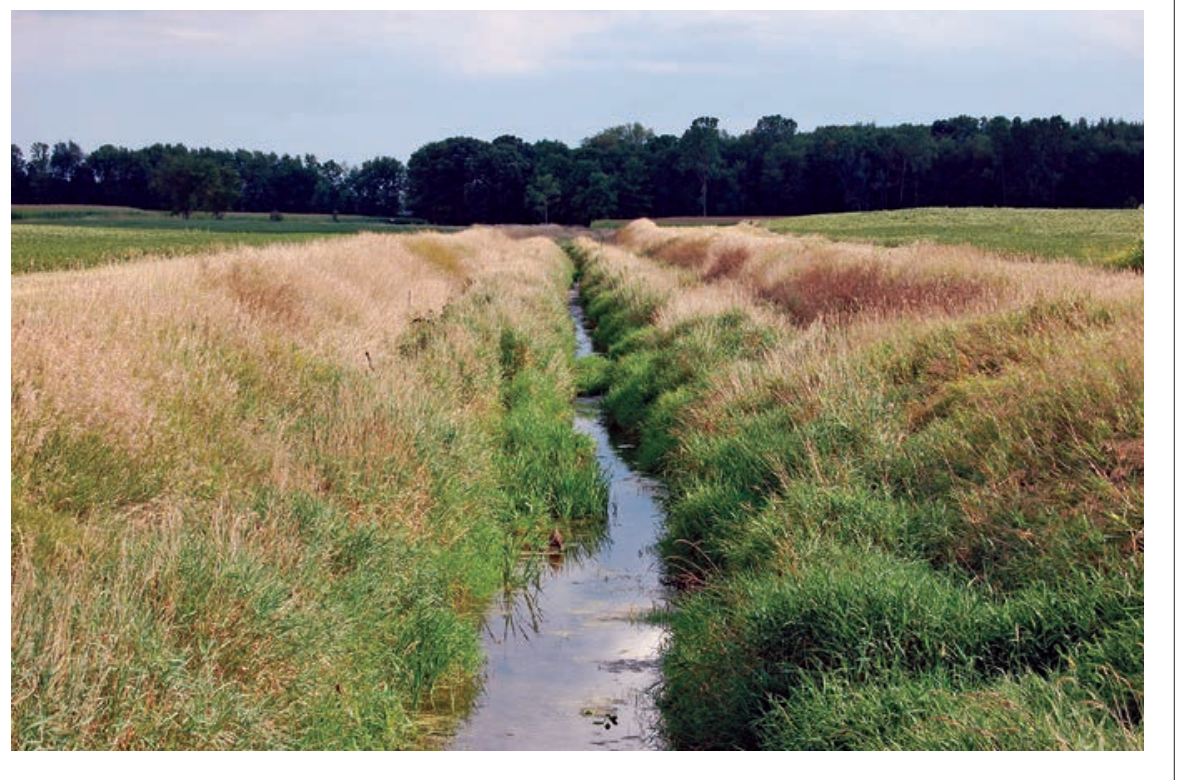

flow conditions, when $\mathrm{NO}_{3}$ loading was relatively low $\left(41 \mathrm{~kg} \mathrm{~d}^{-1}\left[90 \mathrm{lb} \mathrm{day}^{-1}\right]\right)$. Using a $\mathrm{N}$ removal simulation tool developed at The Ohio State University, they predicted that if the entire ditch was converted to a two-stage ditch, annual $\mathrm{NO}_{3}-\mathrm{N}$ load would be reduced by approximately $10 \%$ from the watershed.

Estimating sediment and nutrient retention due to depositional processes that form the floodplain benches within natural two-stage ditches is a relatively new area of research. Results of a three-year study (Brooker et al. 2014) at 15 sites in Ohio and Indiana found sequestration of 50 to $150 \mathrm{~kg}$ $\mathrm{m}^{-3}$ (3 to $9 \mathrm{lb} \mathrm{ft}^{-3}$ ) of total carbon (C) and deposition of 2 to $11 \mathrm{~kg} \mathrm{~m}^{-3}$ (0.1 to $0.7 \mathrm{lb}$ $\mathrm{ft}^{-3}$ ) of total $\mathrm{N}$ in floodplain bench sediments. While the mass of total $\mathrm{C}$ and $\mathrm{N}$ was not significantly different by site and across years, there was significant variation by the ecoregion location of sites. In a study of six sites in central Ohio, floodplain bench soil cores consisting of deposited sediments were collected and analyzed for a suite of soil physical and chemical properties that serve as indicators of ecological function (Mecklenburg and Witter 2012). Measured soil organic matter (57 to $283 \mathrm{~g} \mathrm{~kg}^{-1}$ ) and concentrations of total C (33 to $67 \mathrm{~g} \mathrm{~kg}^{-1}$ ) and $\mathrm{N}(1,082$ to $2,210 \mathrm{mg} \mathrm{kg}^{-1}$ ) in floodplain bench soils were similar to or exceeded published ranges in forested and constructed wetlands in the region (Mitsch et al. 2012; Rokosch et al. 2009). Total P concentrations in floodplain bench deposits ranged from 67 to $319 \mathrm{mg} \mathrm{kg}^{-1}$, which is higher than values reported for field soils, but less than concentrations reported for wetland ecosystems (Mitsch and Gosselink 1993). These preliminary results suggest that sediment and nutrient retention due to deposition within agricultural channels may be an important mechanism for attenuating downstream transport of these constituents.

Two-stage ditches may be used as one part of a systems approach to reduce downstream exports of sediment, N, P, and pesticides, and we suggest it is a valuable tool in helping to solve nutrient enrichment problems in the Gulf of Mexico and Great Lakes. A careful analysis should always be performed before installing a two-stage ditch to determine whether the approach is applicable to the site and priorities of land managers. For example, as stream $\mathrm{NO}_{3}$ concentrations increase, denitrification in a two-stage ditch treats a greater mass of $\mathrm{NO}_{3}$, yet the percentage reduction decays (Mulholland et al. 2008). While two-stage ditches with grassed benches might be considered as part of an integrated systems approach to mitigating sediment, nutrient, and pesticide transport, the primary objectives should be to reduce the loads reaching the ditches. We have also found that the approach can run counter to societal desires and recommend that in cases where an unmaintained ditch has established natural grassed benches and is not negatively impacting subsurface drainage, a do-nothing 
approach may provide greater benefits than a perceived need to clean out the ditch.

\section{Wetlands (Natural Resources Conservation Service Conservation Practice Standard Codes 656, 657 Plus Other Programs)}

Prior to settlement, the Upper Mississippi River Basin and Great Lakes region had extensive areas of wetlands, but most of these have been lost in agricultural regions because of extensive drainage improvements (figure 1). By the mid-1980s, wetland losses were near $90 \%$ for most of the US Corn Belt (Dahl 1990; Mitsch and Gosselink 2000). As a result, the region has considerable opportunity for wetland construction and restoration and potential for strategically positioning wetlands to intercept nutrients transported in subsurface flow. Wetlands have the potential to remove a wide variety of contaminants (Howard-Williams 1985; Nixon and Lee 1986; Kadlec and Wallace 2009; Kadlec 2012; Reddy et al. 1999, 2005) and have proven to be effective in reducing nutrient loads from agricultural drainage (Braskerud et al. 2005; Crumpton et al. 2008; Crumpton 2001, 2005; Kovacic et al. 2000; Mitsch et al. 2005a; Reddy et al. 1999). The capacity of wetlands as long-term, sustainable nutrient sinks depends upon either net storage, such as through accumulation in sediments, or upon gaseous losses, such as denitrification.

The processes governing transformation of $\mathrm{N}$ in wetlands are similar to those in soils and in other aquatic systems with similar biogeochemical conditions (Bowden 1987; Crumpton and Goldsborough 1998; Howard-Williams 1985; Kadlec 2012; Kadlec and Wallace 2009; Reddy and Graetz 1988). Under anaerobic conditions that are typical of wetland soils, $\mathrm{NO}_{3}$ serves as a terminal electron acceptor for heterotrophic oxidation of organic C, primarily through denitrification. Wetlands have some capacity for storage of unmineralized organic $\mathrm{N}$ associated with soil accretion. However, denitrification is the primary mechanism for long-term, sustainable $\mathrm{N}$ removal in wetlands and will largely determine the effectiveness of wetlands in reducing nonpoint source $\mathrm{N}$ loads from agricultural landscapes.

Unlike $\mathrm{N}$, wetlands reduce $\mathrm{P}$ loads primarily through retention, which is mainly controlled by three processes. The first of these is the sorption or release of $\mathrm{P}$ by wetland soils, the second is $\mathrm{P}$ accumulation associated with the formation of new biomass, and the third is $\mathrm{P}$ accumulation resulting from the accretion of new wetland soils (Reddy et al. 2005). Neither of the first two processes contributes to the capacity of wetlands for sustainable P retention. Wetlands have a finite capacity for either P sorption on existing sediments or the accumulation of $\mathrm{P}$ in new biomass. The capacity of wetlands for long-term, sustainable retention of $\mathrm{P}$ is due primarily to the accumulation of inorganic and unmineralized organic $\mathrm{P}$ associated with the accretion of newly formed wetland soil (Anderson et al. 2005; Mitsch et al. 2005b).

Depending on prior land use and wetland management, newly constructed or restored wetlands can initially be net exporters of P. In some cases, wetlands on former agricultural land can have relatively high levels of soil $\mathrm{P}$, and with lower redox conditions, newly flooded soils can at least initially release significant amounts of P (Reddy et al. 2005). Similarly, when wetlands are allowed to go dry intermittently, the $\mathrm{P}$ associated with newly accreted and highly organic soils can mineralize through oxidation. When these wetlands are subsequently reflooded and lower redox conditions return, this $\mathrm{P}$ is more susceptible to release (Reddy et al. 1999 2005). Iron ( $\mathrm{Fe}$ ) and aluminum ( $\mathrm{Al})$ content largely control the sorption and release of $\mathrm{P}$ in acid soils, in contrast to alkaline soils in which calcium $(\mathrm{Ca})$ and magnesium $(\mathrm{Mg})$ content exert significant control over the $\mathrm{P}$ exchange. Phosphorus retention can decrease under reducing conditions in wetland soils with the release of $\mathrm{P}$ from $\mathrm{Fe}$ complexes following reduction of $\mathrm{Fe}$ from $\mathrm{Fe}^{+3}$ to $\mathrm{Fe}^{+2}$ (Patrick et al. 1973), and under sufficiently reducing conditions, the binding of Fe by sulfides can further enhance $\mathrm{P}$ release (Brigham et al 2001; Caraco et al. 1989). Under the anaerobic conditions needed for effective removal of $\mathrm{NO}_{3}$ through denitrification, wetlands with high levels of calcite and exchangeable $\mathrm{Ca}$ are more likely to retain $\mathrm{P}$ due to insoluble, Ca-bound P (Bruland and Richardson 2006; Richardson 1999). However, wetlands can become $\mathrm{P}$ sources if sediments are remobilized (Mitsch et al. 2005b), and additional research is needed to document the longterm effectiveness of wetlands as $\mathrm{P}$ sinks and to understand conditions under which stored $\mathrm{P}$ might be released.

Wetland Performance. The effectiveness of nutrient load reduction in wetlands is influenced by a variety of factors including the timing and magnitude of loads, residence times, nutrient concentrations, and the particular chemical species and form of nutrients. On a percentage basis, the nutrient reduction is greatest when residence times are longest and hydraulic loading rates are lowest. However, this is not necessarily true for mass reductions. Although percentage reductions are lower during periods with high loads and short residence times, mass reductions can be very high (i.e., a smaller fraction of a much higher mass load). In addition, both percentage reductions and mass reductions of nutrients associated with suspended sediments can be high during periods of elevated loading and short residence time.

In addition to external drivers related to patterns in nutrient and hydrologic loads, conditions within wetlands including soils, vegetation, and water temperature, can significantly affect nutrient transformation and load reduction. In general, processes responsible for $\mathrm{P}$ retention are less temperature dependent than those involved in the transformation and removal of $\mathrm{NO}_{3}$ (Kadlec and Reddy 2001). For example, potential rates of denitrification would be higher at warmer summer temperatures than during cooler periods of spring and fall. However, in the Upper Mississippi River Basin and Great Lakes region, $\mathrm{NO}_{3}$ loads are generally highest during high flow periods in late winter and spring (Crumpton et al. 2006).

The effectiveness of wetlands in reducing watershed-scale nutrient loads depends primarily on the following factors: wetlands should be placed where they intercept a considerable fraction of the watershed's nutrient loads and should have sufficient size and residence time to significantly reduce these loads. The importance of residence times and hydraulic loading rates were confirmed by a review of nutrient retention results for over 200 wetlands, primarily in North America and Europe, receiving treated wastewater or urban or agricultural runoff (Land et al. 2016). That review concluded that created and restored wetlands can significantly reduce $\mathrm{N}$ and $\mathrm{P}$ loads ( $40 \%$ to $50 \%)$ and that removal efficiencies were significantly correlated with hydraulic loading rate and temperature. Crumpton et al. (2006) summarized the performance of a dozen wetlands treating nonpoint source $\mathrm{NO}_{3}$ loads in Iowa (Crumpton et al. 2006; Davis et al. 1981), Illinois (Hey et al. 1994; Kovacic et al. 2000; Phipps 1997; Phipps and Crumpton 1994), and Ohio (Mitsch et al. 2005a; Zhang and 
Mitsch 2000, 2001, 2002, 2004). On average, these systems reduced $\mathrm{NO}_{3}$ loads by $44 \%$, and a nonlinear function based on hydraulic loading rate explained $69 \%$ of the variability in percentage mass $\mathrm{NO}_{3}$ removal, underscoring the importance of residence time and hydraulic loading rates (Crumpton et al. 2006, 2008; Dale et al. 2010).

Performance expectations for wetlands must take into account landscape position and geographic patterns of precipitation, water yields and hydraulic load, $\mathrm{NO}_{3}$ loads, and temperature. Loading patterns vary considerably depending on position in the landscape and location in the Great Lakes Region, which has a gradient of land use, precipitation, and runoff. Nonpoint source loading rates to wetlands can be expected to vary by more than an order of magnitude across the region, with significant implications for the performance of individual wetlands. Combining a model of wetland $\mathrm{NO}_{3}$ removal efficiency based on hydraulic loading rate with spatially explicit estimates of water yield and $\mathrm{NO}_{3}$ loads across the Upper Mississippi and Ohio River basins showed considerable potential for $\mathrm{NO}_{3}$ load reductions if wetlands were targeted to areas with the highest $\mathrm{NO}_{3}$ concentrations and loads (Crumpton et al. 2006; Crumpton 2005).

\section{Best Management Practices at the Watershed Scale}

It is expected that the use of nutrient management practices at all scales (in-field, edge-of-field, and beyond-the-field) will be beneficial. However, it is difficult to evaluate the effectiveness of conservation practices at the watershed scale and to relate nutrient discharges at a watershed outlet to the various practices that have been implemented within the watershed. The USDA-funded Conservation Effects Assessment Project (CEAP) sought to detect water quality improvements from conservation actions in over a dozen watersheds across the United States. This large, coordinated effort provides an excellent synthesis of approaches and challenges to assessing conservation effectiveness at the watershed scale (Osmond et al. 2012; Tomer and Locke 2011).

Lag times between conservation actions and environmental outcomes pose a challenge to monitoring the effectiveness of conservation at the watershed scale (Sharpley et al. 2009). Only three of the CEAP watersheds were able to detect water qual- ity change with monitoring, and this took about 10 years of data collection (Osmond et al. 2012). In a global review, Meals et al. (2010) found lags between adoption of conservation and detection of measurable water quality improvements to be on the order of decades for sediment, $\mathrm{NO}_{3}$, and $\mathrm{P}$ runoff. Other climatic and land management changes could mask the effects of conservation practices; for instance, in the Maumee River watershed, which covers a heavily subsurface-drained portion of northwest Ohio, water quality monitoring shows significant and unexplained trends of increasing dissolved reactive $\mathrm{P}$ loading to Lake Erie (Stow et al. 2015), despite greater levels of conservation implementation in the region (USDA NRCS 2016).

Because of the challenges to monitoring conservation effectiveness, watershed modeling is frequently used in combination with monitoring, and this pairing was found to be successful in CEAP (Osmond et al. 2012). For example, targeting conservation to pollutant hotspots, also called critical source areas, is a prevailing concept in watershed management (Tomer and Locke 2011; Osmond et al. 2012), but it can be difficult to know where these source areas are without an intensive monitoring effort. Modeling can aid in this determination, but models also require high quality data for inputs and calibration. Still, when watersheds lack long-term and intensive monitoring, watershed modeling is often the only mechanism for assessing conservation effectiveness at the watershed scale (Osmond et al. 2012).

Multiple watershed and water quality models have been used to address these challenges. Moriasi et al. (2012b) provide an overview of 22 manuscripts in a special issue of the Transactions of the American Society of Agricultural and Biological Engineers, which presented 25 hydrologic and water quality models. Their manuscript included discussion on the Soil and Water Assessment Tool (SWAT) model (Arnold et al. 1998, 2012), Agricultural Policy Environmental Extender (APEX; Williams and Izaurralde 2006; Wang et al. 2012), and DRAINMOD (Skaggs et al. 2012b), which are watershed and water quality models commonly used in subsurface-drained agricultural lands. Each of these models has somewhat different scales and applications, but is capable of representing many conservation and management actions in subsurface-drained lands. Another com- monly used model is Spatially Referenced Regression On Watershed Attributes (SPARROW; Alexander et al. 2004), which is a statistical model and is quite distinct from the others as it does not represent land management as the physical and process-based models do. SPARROW has been used extensively for analysis of hotspots in the region (Tuppad et al. 2010a; David et al. 2010; Robertson and Saad 2011; Robertson and Saad 2013), but is not able to simulate most conservation practices.

A variety of in-field, edge-of-field, and in-stream conservation practices have been simulated in SWAT (Arabi et al. 2008) and APEX (Tuppad et al. 2010b). Several studies have used SWAT in subsurface-drained watersheds to simulate in-field management practices, such as the effect of rates, placement, and timing of fertilizer application (Jha et al. 2010; Kalcic et al. 2016; Muenich et al. 2016a; Gildow et al. 2016), the influence of tillage (Bosch et al. 2013; Kalcic et al. 2016), planting a cereal rye (Secale cereale) cover crop (Kalcic et al. 2016), and changing rotations or land use (Jha et al. 2010; Muenich et al. 2016a; Scavia et al. 2017). Vegetated filter strips are an edge-of-field practice frequently simulated in SWAT (Kalcic et al. 2015b, 2016; Muenich et al. 2016a), while practices beyond the field, such as wetlands, are occasionally included in modeling efforts (Kalcic et al. 2015b; Scavia et al. 2017).

Modeling studies can provide insight on the influence of historical management changes in a region. A recent CEAP effort that involved the application of APEX in the western Lake Erie watersheds concluded that current farm management is a substantial improvement over historical practices (USDA NRCS 2016). Others have used the SWAT model for understanding the drivers of historical nutrient loading trends (Daloglu et al. 2012). Also, several have applied SWAT to predict the impact of conservation actions on in-stream water quality, particularly for wildlife benefits (Einheuser et al. 2012; Herman et al. 2015; Keitzer et al. 2016; Muenich et al. 2016b).

An important advantage of watershed models is the ability to predict the effects of "what if" scenarios. While intensive monitoring can show water quality improvements in a given location with a given set of practices, watershed modeling enables assessments of combinations of practices at a range of temporal and spatial scales and across 
geographies, management regimes, and climates. In addition, models can be used with an optimization approach to choose conservation practices for water quality benefit at least cost (Gitau et al. 2004; Arabi et al. 2006; Maringanti et al. 2011; Kaini et al. 2012; Artita et al. 2013; Kalcic et al. 2015b). Others have tested targeting approaches or other predefined watershed management strategies (Jha et al. 2010; Scavia et al. 2017). There is a growing literature of climate change research using the SWAT model, and some studies have looked at conservation effectiveness under changing climates (Bosch et al. 2014; Woznicki and Nejadhashemi 2014). The testing of combinations of practices can show the effectiveness of stacked practices, revealing either synergies or diminishing returns of applying multiple conservation practices simultaneously (Kalcic et al. 2016).

Limitations of Watershed Modeling. While modeling may, in many cases, be the best way to estimate conservation effectiveness at larger scales, it has limitations. For one, watershed and water quality models are complex and require significant resources and expertise to develop and maintain (Osmond et al. 2012). They are best constructed with care, perhaps iteratively over time, and through collaboration with regional stakeholders who can help the modeler understand the practices occurring across the watershed (Kalcic et al. 2016).

Not all practices can be fully represented in models, if at all. Take the SWAT model as an example, the most widely used model for simulating agricultural watersheds because of its representation of so many land management operations, including conservation practices (Arabi et al. 2008): there are currently no routines for simulating floodplain wetlands, and while there are two options for simulating headwater wetlands, one-called "wetlands"-does not currently accept flows from subsurface drainage (Kalcic et al. 2015b), and the other-referred to as "reservoirs"- only work for headwater wetlands that intercept the main channel in a subbasin. SWAT can simulate a lack of tillage, but does not represent the soil health improvements from no-tillage. Similarly, the long-term soil tilth from cover crops is not captured; newer routines, like drainage water management, are in need of validation against field-scale monitoring data; and two-stage ditches, bioreactors, saturated buffers, and many other practices are not currently represented in the model. These areas are ripe for future modeling development and validation.

Watershed models may not accurately predict conservation effectiveness, and in some cases have been found to over-predict performance (Osmond et al. 2012). This may be because they have, to an extent, built-in conservation practice effectiveness, which may not match a given geography or practice implementation. In some cases, they simulate practices to be effective immediately, thereby ignoring the lag time between implementation and water quality improvement. This would be even more likely if existing legacy nutrient and sediment pools on land or in streams is not considered by the model. Time lags such as soil P depletion under reduced fertilization have been demonstrated in the SWAT model (Muenich et al. 2016a), but $\mathrm{P}$ stored in streams, rivers, and reservoirs may be more difficult to simulate. Continued efforts to validate practice effectiveness at the field and reach scales will be needed to verify if models are correct (Tomer and Locke 2011).

There are many sources of model error and uncertainty, and they can severely limit the use of models in assessing conservation effectiveness. Model prediction at gaging stations, where calibration occurs, can be fairly uncertain if there is a lack of measured data. The level of uncertainty increases into the headwaters, where there is unlikely to be data to verify model performance, and may be greatest at the field scale, where assumptions about land management practices are made. Watershed models cannot reliably predict conservation effectiveness without inclusion of correct land management data, which are often proprietary or difficult to obtain (Osmond et al. 2012). It is rare for watershed models to represent individual farm fields, so it can be difficult to relate farm management data to the model inputs, or tie model results to the field scale (Daggupati et al. 2011; Kalcic et al. 2015b; Teshager et al. 2016).

Finally, some climates and land uses are more accurately predicted than others. Fortunately for the Mississippi River Basin and Great Lakes Region, the SWAT model has shown to be robust in wetter climates (Van Liew et al. 2007), and model development has improved considerably in areas with subsurface drainage (Du et al. 2005; Moriasi et al. 2012a; Boles et al. 2015). Overall, large watersheds and ungauged watersheds may have greater uncertainty than smaller, more heavily monitored ones, and further work in smaller, well-monitored watersheds, with model validation at the field scale, can inform work at larger scales (Tomer and Locke 2011).

Influencing Adoption of Conservation in a Watershed. Complex agricultural settings consist of intertwined nutrient management and reduction practices at in-field, edge-offield, and beyond-the-field scales. Practices at the field scale are best understood by the farmer and have the highest likelihood of providing success and an economic benefit to the farmer. Edge-of-field practices are typically more complex, have shorter and less comprehensive knowledge bases, and have uncertain sustainability. However, they are a quick fix to reducing nutrient discharges and primarily consist of treatment strategies. Knowledge on the performance of beyond-the-field strategies is quite variable. Wetlands as treatment systems are widely used and researched, but their performance in reducing exports is complex and highly site specific. Two-stage ditches are a new practice, and knowledge on this practice is in its infancy. Another issue with two-stage ditches is that they remove additional land from agricultural production. As we move further from the field, acceptance by the farmer of any practice diminishes. Therefore, implementing conservation at the watershed level is not a simple task, and it involves cooperation of a multitude of private landowners and operators.

Most conservation practices are voluntarily adopted in the United States, and the chief policy instruments used to encourage adoption are incentive payments. In the United States, the importance of understanding farmers' attitudes towards conservation was one of the lessons learned by CEAP (Osmond et al. 2012). Social scientists and economists have sought to understand the motivations for adoption of practices throughout the world (Knowler and Bradshaw 2007; Prokopy et al. 2008; Baumgart-Getz et al. 2012). They find many different factors can influence adoption rates, depending on social and political contexts (Knowler and Bradshaw 2007). At the smaller scale, the type of practice and its compatibility with a given farm operation are important predictors of uptake (Reimer et al. 2012). Motivations also differ by farm operator and are predicted by positive environmental attitudes, access to information, land tenure, 
and connection to networks (Prokopy et al. 2008; Baumgart-Getz et al. 2012).

Several studies on adoption have taken place in the US Midwest. Reimer et al. (2012) used qualitative methods to determine specific conservation practice factors influencing adoption in two watersheds in Indiana. In analyzing conservation tillage, cover crops, grassed waterways, and filter strips, they found that in addition to practice compatibility to farm operations, relative advantage - the perception of economic or soil health benefits - and the ability to observe benefits differed among practices and influenced rates of adoption. Valentin et al. (2004) surveyed farmers in Kansas and found in-field practices that saved nutrients increased farm profitability, while practices designed to save soil did not influence profitability. Wilson et al. (2014) found that a perception of risk to either profitability or water quality was the best predictor of farmer attitudes towards adopting a new practice in northwest Ohio and emphasized the importance of efficacy, or a belief that specific farm management changes can make a difference. Also in Ohio, Campbell et al. (2011) used a mixture of qualitative and quantitative methods to analyze the role of collaboration in driving behavior change and found that those participating in grass-roots partnerships had increased levels of adoption. In Iowa, Arbuckle's (2013a) farmer surveys found support for two alterative conservation funding approaches: proactive targeting and conservation compliance (Arbuckle 2013a, 2013b). Kalcic et al. (2014) interviewed farmers in Indiana and found that while they agreed conservation money should be targeted to areas of greatest need, they had differing perspectives on how this should be done and the role of governmental intervention.

Overall, these studies conclude that conservation adoption is complex and differs across conservation practices, the needs of individual operators, regional perspectives, and existing policy frameworks. Encouraging conservation adoption is not simply a matter of providing monetary incentives-indeed, such incentives can be counter-productive (Baumgart-Getz et al. 2012; Kalcic et al. 2014). Effective networks and channels for outreach and extension training are also critical (Baumgart-Getz et al. 2012). Conservation programs should be tailored to a region, and practices must be relevant to the needs of the land and its operator.
Adoption is context-specific, and research suggests conservation programming should be flexible and focused on environmental outcomes (Reimer et al. 2014).

\section{Conclusions}

Despite the many options for preventing nutrient and sediment loss at the field scale, the reality is that not all farmland will receive these treatments, and the only (and sometimes best) options for improving water quality will be within streams. In-stream treatment and watershed-scale approaches are an important piece of the conservation toolbox. Both wetlands and two-stage ditches have been used in this region to treat flows from subsurface-drained agricultural areas, and they show promise in capturing both $\mathrm{N}$ and $\mathrm{P}$. In addition to wetlands and twostage ditches, in-stream approaches include using control structures, P filters, or bioreactors within ditches. However, knowledge on how to design these systems to provide a specific performance requirement is inadequate for most settings. To some extent we face this same problem with all beyond-thefield practices, partly because the complexity of the system increases as we move further away from a single source, such as a field, and a single farmer. Typically, within a state there are a few experts with sufficient knowledge to design and estimate the performance of beyond-the-field strategies, but adequate knowledge is not ubiquitous. Indeed, as some of the approaches are fairly new, site-specific knowledge is often inadequate, and our current body of literature contains mixed information that is not easy to translate into separate or bundled BMP strategies. Efforts to address these short-comings are occurring in most states, but further work is needed to assess current knowledge and prioritize knowledge gaps. As technical designs for these practices become more established, clear messaging through education and extension will be imperative to see successful implementation at the scales needed to treat water quality needs in the Mississippi River Basin and Great Lakes regions.

\section{Acknowledgements}

The paper concept and authorship of the manuscript are associated with a Healthy Soils for Healthy Waters Initiative that was funded by a USDA National Institute of Food and Agriculture (NIFA) grant. Partial support for the manuscript development was from the US Environmental Protection Agency (USEPA)'s Great Lakes Restoration Initiative. This work is also partially supported by the National Integrated Water Quality Program Award Number 2012-51130-20255 from the USDA National Institute of Food and Agriculture. The views expressed in this manuscript are solely those of the authors and do not reflect those of the funding agencies or any other entities. With permission from CRC Press, portions of this manuscript are summarized from Chapter 12 in the book Environmental Hydrology 3rd Edition (Ward et al. 2015).

\section{References}

Alexander, R.B., R.A. Smith, and G.E. Schwarz. 2004. Estimates of diffuse phosphorus sources in surface waters of the United States using a spatially referenced watershed model. Water Science \& Technology 49(3):1-10.

Anderson, C.J., R.W. Nairn, and W.J. Mitsch. 2005. Temporal and spatial development of surface soil conditions at two created riverine marshes. Journal of Environmental Quality 34:2072-2081.

Arabi, M., J.R. Frankenberger, B.A. Engel, and J.G. Arnold. 2008. Representation of agricultural conservation practices with SWAT. Hydrological Processes 22(16):3042-3055.

Arabi, M., R.S. Govindaraju, and M.M. Hantush. 2006. Costeffective allocation of watershed management practices using a genetic algorithm. Water Resources Research 42(10).

Arbuckle, J.G. 2013a. Farmer attitudes toward proactive targeting of agricultural conservation programs. Society \& Natural Resources 26(6):625-641.

Arbuckle, J.G. 2013b. Farmer support for extending conservation compliance beyond soil erosion: Evidence from Iowa. Journal of Soil and Water Conservation 68(2):99-109, doi:10.2489/jswc.68.2.99.

Arnold, J.G., D.N. Moriasi, P.W. Gassman, K.C. Abbaspour, M.J. White, R. Srinivasan, C. Santhi, R.D. Harmel, A. van Griensven, M.W. Van Liew, N. Kannan, and M.K. Jha. 2012. SWAT: Model use, calibration, and validation. Transactions of the American Society of Agricultural and Biological Engineers 55(4):1491-1508.

Arnold, J.G., R. Srinivasan, R.S. Muttia, and J.R. Williams. 1998. Large area hydrologic modeling and assessment part I: Model development. Journal of the American Water Resources Association 34:73-89.

Artita, K.S., P. Kaini, and J.W. Nicklow. 2013. Examining the possibilities: Generating alternative watershed-scale BMP designs with evolutionary algorithms. Water Resources Management 27(11):3849-3863.

Baumgart-Getz, A., L.S. Prokopy, and K. Floress. 2012. Why farmers adopt best management practice in the United States: A meta-analysis of the adoption literature. Journal of Environmental Management 96(1):17-25.

Birendra, K.C., B. Schultz, and K. Prasad. 2011. Water management to meet present and future food demand. Irrigation and Drainage 60:348-359.

Birgand, F., R.W. Skaggs, G.M. Chescheir, and J.W. Gilliam. 2007. Nitrogen removal in streams of agricultural 
catchments-A literature review. Critical Reviews in Environmental Science and Technology 37:381-487.

Blann, K.L., J.L. Anderson, G.R. Sands, and B. Vondracek. 2009. Effects of agricultural drainage on aquatic ecosystems:A review. Critical Reviews in Environmental Science and Technology 39(11):909-1001.

Boles, C.M., J.R. Frankenberger, and D.N. Moriasi. 2015.Tile drainage simulation in SWAT2012: Parameterization and evaluation in an Indiana watershed. Transactions of the American Society of Agricultural and Biological Engineers 58(5):1201-1203.

Bosch, N.S., J.D. Allan, J.P. Selegean, and D. Scavia. 2013. Scenario-testing of agricultural best management practices in Lake Erie watersheds. Journal of Great Lakes Research 39(3):429-436.

Bosch, N.S., M.A. Evans, D. Scavia, and J.D. Allan. 2014. Interacting effects of climate change and agricultural BMPs on nutrient runoff entering Lake Erie. Journal of Great Lakes Research 40(3):581-589.

Bowden, W.B. 1987. The biogeochemistry of nitrogen in freshwater wetlands. Biogeochemistry 4:313-348.

Braskerud, B.C., K.S. Tonderski, B. Wedding, R. Bakke, A.G. Blankenberg, B. Ulen, and J. Koskiaho. 2005. Can constructed wetlands reduce the diffuse phosphorus loads to eutrophic water in cold temperate regions? Journal of Environmental Quality 34(6):2145-2155.

Brooker, M., J. Witter, R. Islam, and P.J. Mouser. 2014. Physical and Chemical Properties of Bench Sediments in Self-Formed Agricultural Drainage Channels. American Geophysical Union. Fall Meeting 2014. Washington, DC: American Geophysical Union.

Bruland, G.L., and C.J. Richardson. 2006. An assessment of the phosphorus retention capacity of wetlands in the Painter Creek Watershed, Minnesota, USA: Water, Air, and Soil Pollution 171:169-184.

Campbell, J.T., T.M. Koontz, and J.E. Bonnell. 2011. Does collaboration promote grass-roots behavior change? Farmer adoption of best management practices in two watersheds. Society \& Natural Resources 24(11):1127-1141.

Caraco, N.F., J.J. Cole, and G.E. Likens. 1989. Evidence for sulfate controlled phosphorus release from sediments of aquatic systems. Nature 341:316-318.

Carmichael, W. 2008. World overview - One-hundredtwenty-seven years of research on toxic cyanobacteria - Where do we go from here? In Cyanobacterial Harmful Algal Blooms: State of the Science and Research Needs (Chapter 4), ed. H.K. Hudnell, 105125. New York: Springer Press.

Cotton, J.A., G. Wharton, J.A.B. Bass, C.M. Heppell, and R.S. Wotton. 2006. The effects of seasonal changes to in-stream vegetation cover on patterns of flow and accumulation of sediment. Geomorphology 77:320-334.

Crumpton, W.G. 2001. Using wetlands for water quality improvement in agricultural watersheds:The importance of a watershed scale perspective. Water Science and Technology 44:559-564.
Crumpton, W.G. 2005. Water quality benefits of wetland restoration: A performance-based approach. In The Conservation Reserve Program - Planting for the Future, eds. A.W. Allen and M.W. Vandever, 181-190. Proceedings of a National Conference, Fort Collins, Colorado, June 6-9, 2004. USGS Biological Resources Discipline, Scientific Investigations Report 2005-5145. Washington, DC: US Geological Survey.

Crumpton, W.G., and L.G. Goldsborough. 1998. Nitrogen transformation and fate in prairie wetlands. Great Plains Research 8:57-72.

Crumpton, W.G., D. Kovacic, D. Hey, and J. Kostel. 2008. Potential of wetlands to reduce agricultural nutrient export to water resources in the Corn Belt, 29-42. In Gulf Hypoxia and Local Water Quality Concerns Workshop, American Society of Agricultural and Biological Engineers Publication \#913C0308. Ames, IA: American Society of Agricultural and Biological Engineers.

Crumpton, W.G., G.A. Stenback, B.A. Miller, and M.J Helmers. 2006. Potential benefits of wetland filters for tile drainage systems: Impact on nitrate loads to Mississippi River subbasins. USDA Cooperative State Research, Education, and Extension Service (CSREES) project completion report. Washington, DC: USDA Cooperative State Research, Education, and Extension Service.

Daggupati, P., K.R. Douglas-Mankin, A.Y. Sheshukov, P.L. Barnes, and D.L. Devlin. 2011. Field-level targeting using SWAT: Mapping output from HRUs to fields and assessing limitations of GIS input data. Transactions of the American Society of Agricultural and Biological Engineers 54(2):501-514.

Dahl, T.E. 1990. Wetlands losses in the United States, 1780's to 1980 's. Report to the Congress. Washington, DC: US Department of the Interior, Fish and Wildlife Service.

Dale, V.H., C. Kling, J.L. Meyer, J. Sanders, H. Stallworth, T. Armitage, D. Wangsness, T.S. Bianchi, A. Blumberg, W. Boynton, D.J. Conley, W. Crumpton, M.B. David, D. Gilbert, R.W. Howarth, R. Lowrance, K. Mankin, J. Opaluch, H. Paerl, K. Reckhow, A.N. Sharpley, T.W. Simpson, C. Snyder, and D. Wright. 2010. Hypoxia in the Northern Gulf of Mexico. New York: Springer.

Daloglu, I., K.H. Cho, and D. Scavia. 2012. Evaluating causes of trends in long-term dissolved reactive phosphorus loads to Lake Erie. Environmental Science \& Technology 46(19):10660-10666.

D'Ambrosio, J.L.,A.D.Ward, and J.D.Witter. 2015. Evaluating geomorphic change in constructed two-stage ditches. Journal of the American Water Resources Association 51(4):910-922.

Daniels, R.B. 1960. Entrenchment of the Willow Drainage Ditch, Harrison County, Iowa. American Journal of Science American Journal of Science 258(3):161-176.

David, M.B., L.E. Drinkwater, and G.F. McIsaac. 2010. Sources of nitrate yields in the Mississippi River Basin. Journal of Environmental Quality 39(5):1657-1667.

Davis, C.B., J.L. Baker, A.G. van der Valk, and C.E. Beer. 1981. Prairie pothole marshes as traps for nitrogen and phosphorus in agricultural runoff, 152-163. In Selected Proceedings of the Midwest Conference on Wetland Values and Management, ed. B. Richardson, June 17-19, 1981. St. Paul, MN: The Freshwater Society.

Davis, R.T., J.L. Tank, U.H. Mahl, S.G. Winikoff, and S.S Roley. 2015. The influence of two-stage ditches with constructed floodplains on water column nutrients and sediments in agricultural streams. Journal of the American Water Resources Association 51(4):941:955, doi:10.1111/1752-1688.12341.

Diaz, R.J., and R. Rosenberg. 2008. Spreading dead zones and consequences for marine ecosystems. Science 321(5891):926-929.

Du, B., J.G. Arnold, A. Saleh, and D.B. Jaynes. 2005. Development and application of SWAT to landscapes with tiles and potholes. Transactions of the American Society of Agricultural Engineers 48(3):1121-1133.

Einheuser, M.D., A.P. Nejadhashemi, S.P. Sowa, L. Wang, Y.A. Hamaamin, and S.A. Woznicki. 2012. Modeling the effects of conservation practices on stream health. Science of the Total Environment 435-436 (16):380-391.

Emerson, J.W. 1971. Channelization: A case study. Science 173(3994):325-326.

Evans, R.O., K.L. Bass, M.R. Burchell, R.D. Hinson, R. Johnson, and M. Doxey. 2007. Management alternatives to enhance water quality and ecological function of channelized streams and drainage canals. Journal of Soil and Water Conservation 62(4):308-320.

Frothingham, K.M., B.L. Rhoads, and E.E. Herricks. 2002. A multiscale conceptual framework for integrated ecogeomorphological research to support. Environmental Management 29(1):16-33.

Fry, B.E., A. Ward, and K.W. King. 2012. The frequency of channel-forming discharges in a tributary of Upper Big Walnut Creek, Ohio. Journal of Soil and Water Conservation 67(3):173-182, doi:10.2489/ jswc.67.3.173.

Gildow, M., N.Aloysius, J. Martin, and S. Gebremariam. 2016. Fertilizer placement and application timing as strategies to reduce phosphorus loading to Lake Erie. Journal of Great Lakes Research 42(6):1281-1288.

Gitau, M.W., T.L. Veith, and W.J. Gburek. 2004. Farm-level optimization of BMP placement for cost-effective pollution reduction. Transactions of the American Society of Agricultural Engineers 47(6):1923-1931.

Goolsby, D.A., W.A. Battaglin, B.T. Aulenbach, and R.P. Hooper. 2001. Nitrogen input to the Gulf of Mexico. Journal of Environmental Quality 30:329-336.

Heppell, C.M., G. Wharton, J.A.C. Cotton, J.A.B. Bass, and S.E. Roberts. 2009. Sediment storage in the shallow hyporheic of lowland vegetated river reaches. Hydrological Processes 23(15):2239-2251.

Herman, M.R., A.P. Nejadhashemi, F. Daneshvar, D.M. Ross, S.A. Woznicki, Z. Zhang, and A.H. Esfahanian. 2015. Optimization of conservation practice implementation strategies in the context of stream health. Ecological Engineering 84:1-12. 
Hey, D.L., A.L. Kenimer, and K.R. Barrett. 1994. Water quality improvement by four experimental wetlands. Ecological Engineering 3(4):381-397.

Howard-Williams, C. 1985. Cycling and retention of nitrogen and phosphorus in wetlands: A theoretical and applied perspective. Freshwater Biology 15:391-431.

Jayakaran, A., D. Mecklenburg, A.D. Ward, L.C. Brown, and A. Weekes. 2005. Formation of Fluvial Benches in headwater Channels in the Midwestern Region of the USA. International Agricultural Engineering Journal 14(4):193-208.

Jayakaran, A.D., D.E. Mecklenburg, J.D. Witter, A.D. Ward, and G.E. Powell. 2010. Fluvial processes in agricultural ditches in the North Central Region of the United States and implications for their management. In Agricultural Drainage Ditches: Mitigation Wetlands for the 21st Century, eds. Matthew T. Moore and Robert Kröger, 195-222.

Jayakaran, A.D., and A.D. Ward. 2007. Geometry of inset channels and the sediment composition of fluvial benches in agricultural drainage systems in Ohio. Journal of Soil and Water Conservation 62(4):296-307.

Jha, M.K., C.F. Wolter, K.E. Schilling, and P.W. Gassman. 2010. Assessment of total maximum daily load implementation strategies for nitrate impairment of the Raccoon River, Iowa. Journal of Environmental Quality 39(4):1317-1327.

Jungblut, A.D., S.J. Hoeger, D. Mountfort, B.C. Hitzfeld, D.R. Dietrich, and B.A. Neilan. 2006. Characterization of microcystin production in an Antarctic cyanobacterial mat community. Toxicon 47(3):271-278.

Kadlec, R.H. 2012. Constructed marshes for nitrate removal. Critical Reviews in Environmental Science and Technology 42(9):934-1005.

Kadlec, R.H., and K.R. Reddy. 2001. Temperature effects in treatment wetlands. Water Environment Research 73:543-557.

Kadlec, R.H., and S.D. Wallace. 2009. Treatment Wetlands, 2nd edition. Boca Raton, FL: CRC Press.

Kaini, P., K. Artita, and, J.W. Nicklow. 2012. Optimizing structural best management practices using SWAT and genetic algorithm to improve water quality goals. Water Resources Management 26(7):1827-1845.

Kalcic, M.M., I. Chaubey, and J. Frankenberger. 2015a. Defining Soil and Water Assessment Tool (SWAT) hydrologic response units (HRUs) by field boundaries. International Journal of Agricultural and Biological Engineering 8(3):69-80.

Kalcic, M.M.,J. Frankenberger, and I. Chaubey. 2015b. Spatial optimization of six conservation practices using SWAT in tile-drained agricultural watersheds. Journal of the American Water Resources Association 51(4):956-972.

Kalcic, M.M., C. Kirchhoff, N. Bosch, R.L. Muenich, M. Murray, J. Griffith Gardner, and D. Scavia. 2016. Engaging stakeholders to define feasible and desirable agricultural conservation in Western Lake Erie
Watersheds. Environmental Science \& Technology 50(15):8135-8145.

Kalcic, M., L. Prokopy, J. Frankenberger, and I. Chaubey. 2014. An in-depth examination of farmers' perceptions of targeting conservation practices. Environmental Management 54(4):795-813.

Kallio, R.M. 2010. Evaluation of Channel Evolution and Extreme Event Routing for Two-Stage Ditches in a Tri-State Region of the USA. Master's thesis, The Ohio State University.

Kallio, S.E. 2009. Determining the Bankfull Discharge Exceedance Potential of Agricultural Ditches in Ohio. Master's thesis, The Ohio State University.

Keitzer, S.C., S.A. Ludsin, S.P. Sowa, G. Annis, J.G. Arnold, P. Daggupati, A.M. Froehlich, M.E. Herbert, M.V.V. Johnson, A.M. Sasson, H. Yen, M.J. White, and C.A. Rewa. 2016. Thinking outside of the lake: Can controls on nutrient inputs into Lake Erie benefit stream conservation in its watershed? Journal of Great Lakes Research 42(6):1322-1331.

King, K.W., M.R. Williams, and N.R. Fausey. 2015. Contributions of systematic tile drainage to watershed scale phosphorus transport. Journal of Environmental Quality 44:486-494.

Kleinman, P.J.A., A.L. Allen, B.A. Needelman, A.N. Sharpley, P.A. Vadas, L.S. Saporito, G.J. Folmar, and R.B. Bryant. 2007. Dynamics of phosphorus transfers from heavily manured coastal plain soils to drainage ditches. Journal of Soil and Water Conservation 62(4):225-235.

Knowler, D., and B. Bradshaw. 2007. Farmers' adoption of conservation agriculture: A review and synthesis of recent research. Food Policy 32(1):25-48.

Kovacic, D.A., M.B. David, L.E. Gentry, K.M. Starks, and R.A. Cooke. 2000. Effectiveness of constructed wetlands in reducing nitrogen and phosphorus export from agricultural tile drainage. Journal of Environmental Quality 29:1262-1274.

Kronvang, B., C.C. Hoffmann, and R. Dorge. 2009. Sediment deposition and net phosphorus retention in a hydraulically restored lowland river floodplain in Denmark: Combining field and laboratory experiments. Marine and Freshwater Research 60(7):638-646.

Kuhnle, R., S.A. Simon, and R. Binger. 1999. Dominant discharge of the incised channels of Goodwin Creek. In Proceedings of the American Society of Civil Engineers (ASCE) Water Resources Engineering Conference. Reston,VA: American Society of Civil Engineers.

Land, M., W. Garneli, A. Grimvall, A.C. Hoffmann, W.J. Mitsch, K.S. Tonderski, and J.T.A. Verhoeven. 2016. How effective are created or restored wetlands for nitrogen and phosphorus removal? A systematic review. Environmental Evidence 5:9.

Landwehr, K.D., and B.L. Rhoads. 2003. Depositional response of a headwater stream to channelization. River Research and Applications 19:77-100.

Maccoux, M.J., A. Dove, S.M. Backus, and D.M. Dolan. 2016. Total and soluble reactive phosphorus loadings to Lake Erie: A detailed accounting by year, basin, country, and tributary. Journal of Great Lakes Research 42(6):1151-65

Magner, J., B. Hansen, T. Sundby, G. Kramer, B. Wilson, and J. Nieber. 2012. Channel evolution of Des Moines Lobe till drainage ditches in southern Minnesota (USA). Environmental Earth Sciences 67(8):2359-2369.

Maringanti, C., I. Chaubey, M. Arabi, and B. Engel. 2011. Application of a multi-objective optimization method to provide least cost alternatives for NPS pollution control. Environmental Management 48(3):448-461.

Meals, D.W., S.A. Dressing, and T.E. Davenport. 2010. Lag time in water quality response to best management practices: A review. Journal of Environmental Quality 39(1):85-96. Mecklenburg, D., and J. Witter. 2012. Self-Forming Stream Design: Stream Restoration by Ecological Succession and Channel Evolution. 4th International Ecosummit: Ecological Sustainability - Restoring the Planet's Ecosystem Services. Columbus, OH: Global Soil Biodiversity Initiative.

Michalak, A.M., E.J. Anderson, D. Beletsky, S. Boland, N.S. Bosch, T.B. Bridgeman, J.D. Chaffin, K. Cho, R. Confesor, I. Daloğlu, and J.V. DePinto. 2013. Recordsetting algal bloom in Lake Erie caused by agricultural and meteorological trends consistent with expected future conditions. Proceedings of the National Academy of Sciences 110(16):6448-6452.

Mitsch, W.J., J.W. Day, L. Zhang, and R.R. Lane. 2005a. Nitrate-nitrogen retention in wetlands in the Mississippi River basin. Ecological Engineering 24:267-278.

Mitsch, W.J., and J.G. Gosselink. 1993. Wetlands. New York: Van Nostrand Reinhold.

Mitsch, W.J., and J.G. Gosselink. 2000. Wetlands. New York: John Wiley and Sons Inc.

Mitsch, W.J., L. Zhang, C.J. Anderson, A.E. Altor, and M.E. Hernandez. 2005b. Creating riverine wetlandsEcological succession, nutrient retention, and pulsing effects. Ecological Engineering 25:510-527.

Mitsch, W.J., L. Zhang, K.C. Stefanik, A.M. Nahlik, C.J. Anderson, B. Bernal, M. Hernandez, and K. Song. 2012. Creating wetlands: Primary succession, water quality changes, and self-design over 15 years. BioScience 62(3):237-250.

Moriasi, D.N., C.G. Rossi, J.G. Arnold, and M.D. Tomer. 2012a. Evaluating hydrology of the Soil and Water Assessment Tool (SWAT) with new tile drain equations. Journal of Soil and Water Conservation 67(6):513-524, doi:10.2489/jswc.67.6.513.

Moriasi, D.N., B.N. Wilson, K.R. Douglas-Mankin, J.G. Arnold, and P.H. Gowda. 2012b. Hydrologic and water quality models: Use, calibration, and validation. Transactions of the American Society of Agricultural and Biological Engineers 55(4):1241-1247.

Muenich, R.L., I. Chaubey, and M. Pyron. 2016a. Evaluating potential water quality drivers of a fish regime shift in the Wabash River using the SWAT model. Ecological Modelling 340:116-125. 
Muenich, R.L., M. Kalcic, and D. Scavia. 2016b. Evaluating the impact of legacy $\mathrm{P}$ and agricultural conservation practices on nutrient loads from the Maumee River watershed. Environmental Science \& Technology 50(15):8146-8154.

Mulholland, P.J., A.M. Helton, G.C. Poole, R.O. Hall, S.K. Hamilton, B.J. Peterson, J.L. Tank, L.R. Ashkenas, L.W Cooper, C.N. Dahm, and W.K. Dodds. 2008. Stream denitrification across biomes and its response to anthropogenic nitrate loading. Nature 452:202-246.

Nanson, G.C., and J.C. Croke. 1992. A genetic classification of floodplains. Geomorphology 4(6):459-486.

Needelman, B.A., P.J.A. Kleinman, J.S. Strock, and A.L.Allen. 2007. Improved management of agricultural drainage ditches for water quality protection: An overview. Journal of Soil and Water Conservation 62(4):171-178.

Nixon, S.W., and V. Lee. 1986. Wetlands and water quality: A regional review of recent research in the United States on the role of freshwater and saltwater wetlands as sources, sinks, and transformers of nitrogen, phosphorus, and various heavy metals. Technical Report Y-86-2. Vicksburg, MS: Army Corp of Engineers.

NRC (National Research Council). 2008. Mississippi River Water Quality and the Clean Water Act. Washington, DC: National Academy Press.

Nunnally, N.R. 1978. Improving channel efficiency without sacrificing fish and wildlife habitat, the case for stream restoration. In Strategies for Protection and Management of Floodplain Wetlands and Other Riparian Ecosystems: Proceedings of the Symposium, Callaway Gardens, Georgia, Symposium General Technical Report WO-12. Washington, DC: USDA Forest Service.

Osmond, D., D. Meals, D. Hoag, M. Arabi, A. Luloff, G. Jennings, M. McFarland, J. Spooner, A. Sharpley, and D. Line. 2012. Improving conservation practices programming to protect water quality in agricultural watersheds: Lessons learned from the National Institute of Food and Agriculture-Conservation Effects Assessment Project. Journal of Soil and Water Conservation 67(5):122A-127A, doi:10.2489/jswc.67.5.122A.

Pappas, E.A., and D.R. Smith. 2007. Effects of dredging an agricultural drainage ditch on water column herbicide concentration, as predicted by fluvarium techniques. Journal of Soil and Water Conservation 62(4):262-268.

Patrick Jr., W.H., S. Gotoh, and B.G. Williams. 1973. Strengite dissolution in flooded soils and sediments. Science 179:564-565

Pavelis, G.A. 1987. Economic survey of farm drainage. In Farm Drainage in the United States: History, Status and Prospects, ed. G.A. Pavelis, 110-136. Washington, DC: USDA Economic Research Service.

Phipps, R.G. 1997. Nitrate Removal Capacity of Constructed Wetlands. PhD dissertation, Iowa State University.

Phipps, R.G., and W.G. Crumpton. 1994. Factors affecting nitrogen loss in experimental wetlands with different hydrologic loads. Ecological Engineering 3:399-408.
Powell, G.E. 2006. Examination, Application, and Evaluation of Geomorphic Principles and Resulting Water Quality in Midwest Agricultural Streams and Rivers. 2006. PhD dissertation, The Ohio State University.

Powell, K.L., and V. Bouchard. 2010. Is denitrification enhanced by the development of natural fluvial morphology in agricultural headwater ditches? Journal of the North American Benthological Society 29(2):761-772.

Powell, G.E., D. Mecklenburg, and A.D. Ward. 2006. Evaluating channel-forming discharges: A study of large rivers in Ohio. Transactions of the American Society of Agricultural and Biological Engineering 49(1):35-46.

Powell, G.E., A.D. Ward, D.E. Mecklenburg, and A.D. Jayakaran. 2007a. Two-stage channel systems: Part 1, a practical approach for sizing agricultural ditches. Journal of Soil and Water Conservation 62(4):277-286.

Powell, G.E., A.D. Ward, D.E. Mecklenburg, J. Draper, and W. Word. 2007b. Two-stage channel systems: Part 2, case studies. Journal of Soil and Water Conservation 62(4):287-296

Prokopy, L.S., K. Floress, D. Klotthor-Weinkauf, and A. Baumgart-Getz. 2008. Determinants of agricultural best management practice adoption: Evidence from the literature. Journal of Soil and Water Conservation 63(5):300-311, doi:10.2489/jswc.63.5.300.

Rabalais, N.N., R.J. Diaz, L.A. Levin, R.E. Turner, D. Gilbert, and J. Zhang. 2010. Dynamics and distribution of natural and human-caused hypoxia. Biogeosciences 7(2):585-619

Reddy, K.R., and D.A. Graetz. 1988. Carbon and nitrogen dynamics in wetland soils. In The Ecology and Management of Wetlands, eds. D.D. Hook, H.K. Smith, and W.H. McKee, 307-318. Portland, OR: Timber Press.

Reddy, K.R., R.H. Kadlec, E. Flag, and P.M. Gale. 1999 Phosphorus retention in streams and wetlands: A review. Critical Reviews in Environmental Science and Technology 29:83-146.

Reddy, K.R., R.G. Wetzel, and R.H. Kadlec. 2005 Biogeochemistry of phosphorus in wetlands. In Phosphorus: Agriculture and the Environment, 263-316. Agronomy Monograph No. 46. Madison, WI: American Society of Agronomy, Crop Science Society of America, and Soil Science Society of America.

Reimer, A., A. Thompson, L.S. Prokopy, J.G. Arbuckle, K. Genskow, D. Jackson-Smith, G. Lynne, L. McCann, L.W. Morton, and P. Nowak. 2014. People, place, behavior, and context: A research agenda for expanding our understanding of what motivates farmers' conservation behaviors. Journal of Soil and Water Conservation 69(2):57A-61A, doi:10.2489/jswc.69.2.57A

Reimer, A.P., D.K. Weinkauf, and L.S. Prokopy. 2012. The influence of perceptions of practice characteristics: An examination of agricultural best management practice adoption in two Indiana watersheds. Journal of Rural Studies 28(1):118-128.
Rhoads, B.L., and K.D. Massey. 2012. Flow structure and channel change in a sinuous grass-lined stream within an agricultural drainage ditch: Implications for ditch stability and aquatic habitat. River Research and Applications 28(1):39-52.

Rhoads, B.L., D. Wilson, M.A. Urban, and E.E. Herricks. 1999. Interaction between scientists and nonscientists in community-based watershed management: Emergence of the concept of stream naturalization. Environmental Management 24(3):297-308.

Richardson, C.J. 1999.The role of wetlands in storage, release, and cycling of phosphorus on the landscape-A 25-year retrospective. In Phosphorus Biogeochemistry in SubTropical Ecosystems, ed. K.R. Reddy. Boca Raton, FL CRS Press/Lewis Publishers.

Ritter, D.F. 1979. The effects of channelization on a highenergy river. Environmental Geology 3:29-38.

Ritzema, H.P., H.J. Nijland, and F.W. Croon. 2006. Subsurface drainage practices: From manual installation to largescale implementation. Agricultural Water Management 86:60-71.

Robertson, D.M., and D.A. Saad. 2011. Nutrient inputs to the laurentian great lakes by source and watershed estimated using SPARROW watershed models. Journal of the American Water Resources Association 47(5):1011-1033.

Robertson, D.M., and D.A. Saad. 2013. SPARROW models used to understand nutrient sources in the Mississippi/ Atchafalaya River Basin. Journal of Environmental Quality 42(5):1422-1440.

Rokosch, A.E., V. Bouchard, S. Fennessy, and R. Dick. 2009. The use of soil parameters as indicators of quality in forested depressional wetlands. Wetlands 29:666-677.

Roley, S.S., J.L. Tank, N.A. Griffiths, R.O. Hall, and R.T. Davis. 2014. The influence of floodplain restoration on whole-stream metabolism in an agricultural stream: Insights from a 5-year continuous data set. Freshwater Science 33:1043-1059, doi:10.1086/677767.

Roley, S.S., J.L.Tank, M.L.Stephen, L.T.Johnson, J.J. Beaulieu, and J.D. Witter. 2012a. Floodplain restoration enhances denitrification and reach-scale nitrogen removal in an agricultural stream. Ecological Applications 22:281-297.

Roley, S.S., J.L. Tank, and M.A.Williams. 2012b. Hydrologic connectivity increases denitrification in the hyporheic zone and restored floodplains of an agricultural stream. Journal of Geophysical Research 117.

Royer, T.V., M.B. David, and L.E. Gentry. 2006. Timing of riverine export of nitrate and phosphorus from agricultural watersheds in Illinois: Implications for reducing nutrient loading to the Mississippi River. Environmental Science \& Technology 40:4126-4131.

Scavia, D., J.V. DePinto, and I. Bertani. 2016. A multimodel approach to evaluating target phosphorus loads for Lake Erie. Journal of Great Lakes Research 42(6):1139-50.

Scavia, D., M.M. Kalcic, R.L. Muenich, J. Read, N. Aloysius, I. Bertani, C. Boles, R. Confesor, J. DePinto, M. Gildow, 
J. Martin, T. Redder, D. Robertson, S. Sowa, Y. Wang, and H.Yen. 2017. Multiple SWAT models guide strategies for agricultural nutrient reductions. Frontiers in Ecology and the Environment 15(3):126-132, doi:10.1002/fee.1472.

Schumm, S.A. 1981. Evolution and response of the fluvial system, sedimentologic implications. http://archives.datapages.com/ data/sepm_sp/SP31/Evolution_and_Response.pdf.

Shady, A.M. 1989. Irrigation, Drainage and Flood Control in Canada. Ottawa, Canada: Canadian International Development Agency.

Sharpley, A.N., P.J. Kleinman, P. Jordan, L. Bergström, and A.L. Allen. 2009. Evaluating the success of phosphorus management from field to watershed. Journal of Environmental Quality 38(5):1981-1988.

Simon, A., W. Dickerson, and A. Heins. 2004. Suspendedsediment transport rates at the 1.5-year recurrence interval for ecoregions of the United States: Transport conditions at the bankfull and effective discharge? Geomorphology 58:243-262.

Simon, A., and C.R. Hupp. 1986. Channel evolution in modified Tennessee channels. Proceedings of the Fourth Federal Interagency Sedimentation Conference, March 24-27. Las Vegas, NV: US Geological Survey.

Simon, A., and M. Rinaldi. 2006. Disturbance, stream incision, and channel evolution: The roles of excess transport capacity and boundary materials in controlling channel response. Geomorphology 79(3):361-383.

Skaggs, R.W., M.A. Breve, and J.W. Gilliam. 1994. Hydrologic and water quality impacts of agricultural drainage. Critical Reviews of Environmental Science \& Technology 24:1-32.

Skaggs, R.W., N.R. Fausey, and R.O. Evans. 2012a. Drainage Water Management. Journal of Soil and Water Conservation 67(6):167A-172A, doi:10.2489/ jswc.67.6.167A.

Skaggs, R.W., M.A. Youssef, and G.M. Chescheir. 2012b. DRAINMOD: Model use, calibration, and validation. Transactions of the American Society of Agricultural and Biological Engineers 55(4):1509-1522.

Smith, D.R. 2009. Assessment of in-stream phosphorus dynamics in agricultural drainage ditches. Science of the Total Environment 407:3883-3889.

Smith, D.R., and C. Huang. 2010. Assessing nutrient transport following dredging of agricultural drainage ditches. Transactions of the American Society of Agricultural and Biological Engineers 53(2):429-436.

Smith, D.R., and E.A. Pappas. 2007. Effect of ditch dredging on the fate of nutrients in deep drainage ditches of the Midwestern United States. Journal of Soil and Water Conservation 62(4):252-261.

Stow, C.A., Y. Cha, L.T. Johnson, R. Confesor, and R.P. Richards. 2015. Long-term and seasonal trend decomposition of Maumee River nutrient inputs to western Lake Erie. Environmental Science \& Technology 49(6):3392-400.

Strock, J.S., C.J. Dell, and J.P. Schmidt. 2007. Managing natural processes in drainage ditches for nonpoint source nitrogen control. Journal of Soil and Water Conservation 62(4):188-196.

Strock, J.S., P.J. Kleinman, K.W. King, and J.A. Delgado. 2010. Drainage water management for water quality protection. Journal of Soil and Water Conservation 65(6):131A-136A, doi:10.2489/jswc.65.6.131A.

Teshager, A.D., G. Misgna, P.W. Gassman, S. Secchi, and J.T. Schoof. 2016. Modeling agricultural watersheds with the Soil and Water Assessment Tool (SWAT): Calibration and validation with a novel procedure for spatially explicit HRUs. Environmental Management 1-18.

Tomer, M.D., and M.A. Locke. 2011. The challenge of documenting water quality benefits of conservation practices: A review of USDA-ARS's conservation effects assessment project watershed studies. Water Science and Technology 64(1):300-310.

Tuppad, P., K.R. Douglas-Mankin, and K.A. McVay. 2010a. Strategic targeting of cropland management using watershed modeling. Agricultural Engineering International: CIGR Journal 12(3-4):12-24.

Tuppad, P., C. Santhi, X. Wang, J.R. Williams, R. Srinivasan, and P.H. Gowda. 2010b. Simulation of conservation practices using the APEX model. Applied Engineering in Agriculture 26(5):779-794.

USDA NRCS (Natural Resources Conservation Service). 2007. Part 654 Stream Restoration Design National Engineering Handbook. Washington, DC: USDA Natural Resources Conservation Service.

USDA NRCS. 2014. USDA NRCS Conservation Practice Standard 582 for Open Channels in Ohio. https://efotg. sc.egov.usda.gov/references/public/OH/OH_582_ OpenChan_11-12-14.pdf.

USDA NRCS. 2016. Effects of Conservation Practice Adoption on Cultivated Cropland Acres in Western Lake Erie Basin, 2003-06 and 2012. 120 pp.

Valentin, L., D.J. Bernardo, and T.L. Kastens. 2004. Testing the empirical relationship between best management practice adoption and farm profitability. Applied Economic Perspectives and Policy 26(4):489-504.

Van Liew, M.W., T.L. Veith, D.D. Bosch, and J.G. Arnold. 2007. Suitability of SWAT for the conservation effects assessment project: Comparison on USDA agricultural research service watersheds. Journal of Hydrologic Engineering 12(2):173-189.

Västilä, K., and J. Järvelä. 2011. Environmentally preferable two-stage drainage channels: Considerations for cohesive sediments and conveyance. International Journal of River Basin Manage 9(3-4):171-180.

Västilä, K., J. Järvelä, and H. Koivusalo. 2016. Flowvegetation-sediment interaction in a cohesive compound channel. Journal of Hydraulic Engineering 142(1):04015034.

Vollmer-Sanders, C., A. Allman, D. Busdeker, L.B. Moody, and W.G. Stanley. 2016. Building partnerships to scale up conservation: 4R Nutrient Stewardship Certification Program in the Lake Erie watershed. Journal of Great Lakes Research 42(6):1395-402.
Walling, D.E., and C.M. Amos. 1999. Source, storage and mobilisation of fine sediment in a chalk stream system. Hydrological Processes 13:323-340.

Wang, X., J.R. Williams, P.W. Gassmann, C. Baffaut, R.C. Izaurralde, J. Jeong, and J.R. Kiniry. 2012. EPIC and APEX: Model use, calibration, and validation. Transactions of the American Society of Agricultural and Biological Engineers 55(4):1447-1462.

Ward, A.D., A.D. Jayakaran, D.E. Mecklenburg, G.E. Powell, and J. Witter. 2008. Two-Stage Channel Geometry: Active Floodplain Requirements. Encyclopedia of Water Science, 2nd edition, ed. Stanley Trimble. Boca Raton, FL:Taylor \& Francis, CRC Press.

Ward,A.D., S.W.Trimble, S.R. Burckhard, and J.G. Lyon. 2015. Environmental Hydrology Boca Raton, FL: CRC Press.

Watson, S., C. Miller, G.Arhonditsis, G. Boyer,W. Carmichael, M. Charlton, R. Confesor, D. Depew, T. Höök, S. Ludsin, G. Matisoff, S. McElmurry, M. Murray, R. Peter Richards, Y. Rao, M. Steffen, and S. Wilhelm. 2016. The re-eutrophication of Lake Erie: Harmful algal blooms and hypoxia. Harmful Algae 56:44-66.

Williams, J.R., and R.C. Izaurralde. 2006. The APEX model. Watershed Models 437-482.

Wilson, R.S., G. Howard, and E.A. Burnett. 2014. Improving nutrient management practices in agriculture: The role of risk-based beliefs in understanding farmers' attitudes toward taking additional action. Water Resources Research 50(8):6735-6746.

Witter, J.D. 2013. Alternative Design Options for Open Channels: Two-Stage Ditches and Self-Forming Channels. https://www.agrentools.com/wp-content/ uploads/2016/03/Alternative-Design-Options-forOpen-Channels.pdf.

Woznicki, S.A., and A.P. Nejadhashemi. 2014. Assessing uncertainty in best management practice effectiveness under future climate scenarios. Hydrological Processes 28(4):2550-2566.

Zhang, L., and W.J. Mitsch. 2000. Hydrologic budgets of the two Olentangy River experimental wetlands, 1994-99. In Olentangy River Wetland Research Park, Annual Report 1999, eds. W.J. Mitsch and L. Zhang, 41-46. Columbus, OH:The Ohio State University.

Zhang, L., and W.J. Mitsch. 2001. Water budgets of the two Olentangy River experimental wetlands in 2000. In Olentangy River Wetland Research Park, Annual Report 2000, eds. W.J. Mitsch and L. Zhang, 17-28. Columbus, OH:The Ohio State University.

Zhang, L., and W.J. Mitsch. 2002. Water budgets of the two Olentangy River experimental wetlands in 2001. In Olentangy River Wetland Research Park, Annual Report 2001, eds. W.J. Mitsch and L. Zhang, 23-34. Columbus, OH:The Ohio State University.

Zhang, L., and W.J. Mitsch. 2004. Water budgets of the two Olentangy River experimental wetlands in 2003. In Olentangy River Wetland Research Park, Annual Report 2003, eds. W.J. Mitsch and L. Zhang, 39-52. Columbus, OH:The Ohio State University. 